\title{
OPEN
}

\section{Author Correction: Intestinal crypts recover rapidly from focal damage with coordinated motion of stem cells that is impaired by aging}

Jiahn Choi ${ }^{1}$, Nikolai Rakhilin², Poornima Gadamsetty ${ }^{1}$, Daniel J. Joe ${ }^{1}$, Tahmineh Tabrizian $^{4}$, Steven M. Lipkin ${ }^{3}$, Derek M. Huffman ${ }^{4}$, Xiling Shen $\mathbb{1}^{2}{ }^{2}$ Nozomi Nishimura ${ }^{1}$

Correction to: Scientific Reports https://doi.org/10.1038/s41598-018-29230-y, published online 20 July 2018

Supplementary material containing SolidWorks files for 3D printing the scaffold was omitted from the original version of this Article. This has been corrected in the HTML version of the Article; the PDF version was correct at time of publication.

(c) (i) Open Access This article is licensed under a Creative Commons Attribution 4.0 International License, which permits use, sharing, adaptation, distribution and reproduction in any medium or format, as long as you give appropriate credit to the original author(s) and the source, provide a link to the Creative Commons license, and indicate if changes were made. The images or other third party material in this article are included in the article's Creative Commons license, unless indicated otherwise in a credit line to the material. If material is not included in the article's Creative Commons license and your intended use is not permitted by statutory regulation or exceeds the permitted use, you will need to obtain permission directly from the copyright holder. To view a copy of this license, visit http://creativecommons.org/licenses/by/4.0/.

(c) The Author(s) 2019

\footnotetext{
${ }^{1}$ Nancy E. and Peter C. Meinig School of Biomedical Engineering, Cornell University, Ithaca, 14853, USA. ${ }^{2}$ Department of Biomedical Engineering, Duke University, Durham, North Carolina, 27708, USA. ${ }^{3}$ Departments of

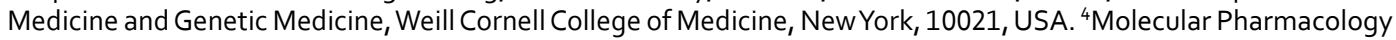
and Medicine, Albert Einstein College of Medicine, Bronx, New York, 10461, USA. Correspondence and requests for materials should be addressed to N.N. (email: nn62@cornell.edu)
} 